\title{
Analisis Perbandingan Proporsi Pengeluaran Pangan dan Tingkat Kecukupan Energi dan Protein Berdasarkan Konsep Pengukuran Ketahanan Pangan pada Rumah Tangga Program dan Rumah Tangga Non-Program Kawasan Mandiri Pangan di Kecamatan Seulimeum Kabupaten Aceh Besar \\ (Comparative Analysis of Food Expenditure Proportions and Adequacy Levels of Calory and Protein Based on the Concept of Food Security Measurement on The Participant and Non-Participant Household of Kawasan Mandiri Pangan Program in Seulimeum District, Aceh Besar Regency)
}

\author{
Naufal Mutawakkil ${ }^{1}$, Elly Susanti ${ }^{1}$, Safrida $^{1 *}$ \\ ${ }^{1}$ Program Studi Agribinis, Fakultas Pertanian, Universitas Syiah Kuala \\ *Corresponding author: safrida@unsyiah.ac.id
}

\begin{abstract}
Abstrak. Berdasarkan konsep pengukuran ketahanan pangan pada tingkat rumah tangga, proporsi pengeluaran pangan dari pengeluaran total yang tinggi merupakan indikasi dari tingkat ketahanan pangan yang rendah. Variabel yang sama dapat dilihat dari tingkat kecukupan energi dan protein, di mana jika tingkat kecukupan di bawah konsumsi anjuran berdasarkan angka kecukupan maka rumah tangga diindikasikan mengalami kerawanan pangan. Penilitian ini merupakan studi cross sectional dengan membandingkan nilai proporsi pengeluaran pangan, tingkat kecukupan energi dan protein antara dua kelompok responden yaitu rumah tangga yang sudah menjadi penerima program dan sudah memasuki tahun keempat dengan rumah tangga bukan peserta program. Hasil penilitian menunjukkan menunjukkan bahwa sebagian besar tingkat pengeluaran rumah tangga pada kelompok penerima $(86,7 \%)$ dan kelompok bukan penerima $(73,3 \%)$ termasuk dalam kategori tingkat proporsi pengeluaran pangan rendah, yang berarti kedua kelompok responden dari dimensi pengeluaran pangan sebagian besar tergolong baik. Sebagian besar tingkat kecukupan energi rumah tangga pada kelompok penerima termasuk dalam kategori cukup (56,7\%), sedangkan rumah tangga bukan penerima sebagian besar temasuk dalam kategori kurang $(60,0 \%)$. Tingkat konsumsi protein kedua kedua kelompok rumah tangga penerima dan bukan penerima sebagian besar termasuk dalam kategori kurang dengan nilai masing-masingnya 63,3\% dan 76,7\%. Hasil uji Mann-Whitney menunjukkan bahwa terdapat perbedaan yang signifikan antara persentase pengeluaran pangan pada kedua kelompok (nilai $\mathrm{P}=0,000$ ), sedangkan variabel tingkat konsumsi energi dan protein tidak terdapat perbedaan yang signifikan pada kedua kelompok dengan nilai signifikansi masing-masing nilai $\mathrm{P}=0,074$ dan $\mathrm{P}=0,115$.
\end{abstract}

Kata Kunci: Pengeluaran pangan, tingkat kecukupan energi dan protein, analisis komparatif

\begin{abstract}
Based on the concept of measuring food security at the household level, a high proportion of food expenditure from total expenditure is an indication of a low level of food security. The same variable can be seen from the level of calory and protein adequacy, where if the level of adequacy is below the recommended consumption based on the adequacy rate, the household is indicated to be experiencing food insecurity. This research is a cross sectional study by comparing the proportion of food expenditure, calory and protein adequacy levels between two groups of respondents, namely households that have become program recipients and have entered their fourth year with households that are not program participants. The results of the study indicate that most of the household expenditure levels in the recipient group (86.7\%) and non-recipient group (73.3\%) are included in the category of low food expenditure proportion level, which means that the two groups of respondents from the food expenditure dimension are mostly classified as good. Most of the household energy adequacy level in the recipient group is in the sufficient category (56.7\%), while the non-recipient households are mostly in the less category $(60.0 \%)$. The level of protein consumption of the two groups of beneficiary and non-recipient households is mostly in the less category with values of $63.3 \%$ and $76.7 \%$. The results of the Mann-Whitney test showed that there was a significant difference between the percentage of food expenditure in the two groups $(\mathrm{P}$ value $=0.000$ ), while the calory and protein consumption level variables there was no significant difference in the two groups with a significance value of each $\mathrm{P}$ value $=0.074$ and $\mathrm{P}=0.115$.
\end{abstract}

Keywords: Food expenditure, calory and protein adequacy level, comparative analysis 


\section{PENDAHULUAN}

Pengeluaran pangan merupakan salah satu indikator yang digunakan untuk menganalisis ketahanan pangan rumah tangga. Tingkat pengeluaran pangan adalah biaya yang dikeluarkan untuk pangan oleh suatu rumah tangga dalam waktu setiap bulannya dan membandingkannya dengan total pengeluaran per bulan. Amaliyah dan Handayani (2011), mengemukakan bahwa semakin besar tingkat pengeluaran pangan berarti ketahanan pangan suatu rumah tangga semakin berkurang, dan semakin tingginya kesejahteraan masyarakat suatu negara, maka besar tingkat pengeluaran pangan rumah tangganya semakin kecil, demikian pula sebaliknya. Menurut Ilham dan Sinaga (2007) tingkat pengeluaran pangan layak dijadikan indikator ketahanan pangan karena mempunyai sifat hubungan yang erat dengan berbagai ukuran ketahanan pangan yaitu tingkat konsumsi keanekaragaman pangan dan pendapatan, serta memiliki ciri dapat diukur dengan angka, cukup sederhana untuk memperoleh dan menafsirkannya, objektif dan responsif terhadap perubahan-perubahan akibat adanya perubahan kondisi perekonomian, kebijakan dan program pembangunan. Ilham dan Sinaga (2007) juga mengemukanan bahwa ada hubungan antara tingkat pengeluaran pangan dengan ketahanan pangan rumah tangga, di mana jika tingkat pengeluaran pangan semakin besar maka semakin rendah tingkat ketahanan rumah tangga tersebut. Pengukuran ketahanan pangan di tingkat rumah tangga dapat ditentukan secara kuantitatif dan kualitatif. Metode kuantitatif menurut Smith (2002) dalam Fathonah dan Prasodjo (2011), dilakukan dengan menggunakan survei pengeluaran rumah tangga (household expenditure survey) dan asupan pangan individu (individual food intake).

Berdasarkan laporan data Indikator Kesejahteraan Rakyat Aceh Besar (2019), Konsumsi energi dan protein di masyarakat Aceh Besar masih di bawah nilai anjuran yang disepakati pada Widyakarya Nasional Pangan dan Gizi (WNPG) X tahun 2012 dalam Permenkes Nomor 75 tahun 2013. Untuk rata-rata konsumsi energi bernilai $2.150 \mathrm{kkal}$ per kapita per hari dan rata-rata konsumsi protein bernilai 57 gram per kapita per hari. Pada tahun 2019 rata-rata konsumsi energi 80\% masyarakat dengan golongan pengeluaran menengah kebawah di Aceh Besar adalah sebesar 1762,7 kkal per kapita dan rata-rata konsumsi protein sebesar 50,5 gram per kapita. Dalam laporan tersebut juga diketahui, masyarakat Kabupaten Aceh Besar dengan kelompok pengeluaran menengah ke bawah menengah memiliki persentase pengeluaran pangan lebih tinggi daripada pengeluaran non-pangan. Kondisi tersebut berdasarkan Purwantini dan Ariani (2008) adalah kondisi di mana kesejahteraan rumah tangga pada aspek pengeluaran rumah tangga masih rendah. Ilham dan Sinaga (2007) juga mengemukakan bahwa menurunnya kesejahteraan suatu rumah tangga menyebabkan daya beli menjadi rendah akibatnya tingkat pengeluaran rumah tangga untuk pangan menjadi meningkat.

\section{Tujuan Penelitian}

Penelitian ini bertujuan untuk menganalisis perbandingan tingkat proporsi pengeluaran pangan, tingkat kecukupan energi dan tingkat kecukupan protein pada dua kelompok rumah tangga yaitu rumah tangga program dan rumah tangga non-program kawasan mandiri pangan di Kecamatan Seulimeum Kabupaten Aceh Besar.

\section{METODE PENELITIAN}

\section{Lokasi dan Waktu Penelitian}

Penelitian dilakukan pada bulan November sampai dengan Desember 2019, yang meliputi pengumpulan data, pengolahan data, analisis dan interpretasi data. Lokasi penelitian 
dilakukan di 4 desa di Kecamatan Seulimum Kabupaten Aceh Besar. Desa dengan rumah tangga program yaitu Iboeh Tanjong dan Iboeh Tunong sedangkan desa dengan rumah tangga non program yaitu Bayu dan Bate Lhee. Pemilihan 2 desa dengan rumah tangga program dilakukan berdasarkan keikutsertaan kedua desa tersebut pada program Kawasan Mandiri Pangan tahun 2014 dan sudah memasuki tahapan kemandirian pada tahun 2019 (Dinas Pangan Aceh, 2018). Adapun 2 desa dengan rumah tangga non program ditentukan berdasarkan kesamaan karakteristik wilayah dengan dua desa sebelumnya yaitu pada aspek kriteria luas desa 2 sampai $4 \mathrm{~km}^{2}$, jumlah penduduk yang termasuk ke dalam klasifikasi desa kecil dengan jumlah penduduk kurang dari 800 jiwa dan seluruh desa merupakan klasifikasi swakarya atau desa yang sedang berkembang (Badan Pusat Statistik Aceh Besar, 2019).

\section{Objek dan Ruang Lingkup Penelitian}

Objek pada penelitian ini adalah rumah tangga penerima program dan rumah tangga bukan penerima program Kawasan Mandiri Pangan. Adapun ruang lingkup penelitian ini dibatasi pada pengeluaran rumah tangga dan konsumsi pangan rumah tangga, di mana pada variabel pengeluaran diukur proporsi pengeluaran pangan (\%) dan pada variabel konsumsi dibatasi pada konsumsi energi dan protein rumah tangga dengan melihat tingkat kecukupan zat gizi (\%) berdasarkan angka kecukupan (\%).

\section{Populasi dan Sampel}

Keseluruhan populasi pada empat desa lokasi penelitian adalah 387 rumah tangga, dengan proporsi rumah tangga program sebanyak 196 rumah tangga dan proporsi rumah tangga non program sebanyak 191 rumah tangga. Penentuan jumlah sampel dalam penelitian ditentukan berdasarkan teori pengambilan sampel oleh Arikunto (2013), dimana sampel yang diambil sebesar $15 \%$ dengan jumlah masing-masing 15 rumah tangga pada 4 desa lokasi.

\section{Metode Analisis}

Analisis data yang dilakukan adalah analisis deskriptif dan uji Mann-Whitney $U$ dengan bantuan paket program Microsoft Excel dan Statistical Program for Social Science (SPSS) 16.0 for Windows. Analisis deskriptif dilakukan untuk menggambarkan variabel pengeluaran rumah tangga dan variabel konsumsi energi maupun protein rumah tangga yang disajikan dalam bentuk tabel. Kemudian dilakukan analisis uji Mann-Whitney $U$ untuk melihat perbedaan pada seluruh variabel yang telah disebutkan di atas. Tahapan analisis pada penelitian ini adalah sebagai berikut.

\section{Pengeluaran Rumah Tangga}

Perhitungan pengeluaran total rumah tangga seacara umum terdiri atas dua komponen, yaitu pengeluaran pangan dan pengeluaran non-pangan. Perhitungan pengeluaran total digunakan rumus sebagai berikut:

Keterangan:

$$
P G T=P P+P N P
$$

PGT : Pengeluaran total rumah tangga (rupiah/bulan)

PP : Pengeluaran pangan (rupiah/bulan)

PNP : Pengeluaran non-pangan (rupiah/bulan) 
Tingkat pengeluaran pangan adalah biaya yang dikeluarkan untuk pangan oleh suatu rumah tangga dalam waktu setiap bulannya dan membandingkannya dengan total pengeluaran per bulan (Yudaningrum, 2011 dalam Arida et al., 2015), dirumuskan sebagai berikut:

$$
\text { Proporsi Pengeluaran Pangan }=\frac{\text { Pengeluaran pangan }}{\text { Pengeluaran total }} \times 100 \%
$$

Berdasarkan metode pengukuran ketahanan pangan dengan indikator proporsi pengeluaran pangan dari Jonsson dan Toole (1991) dalam Maxwell et al. (1992). Batasan tingkat pengeluaran pangan adalah $60 \%$ dari total pengeluaran, di mana proporsi pengeluaran pangan dikatakan rendah jika bernilai sebesar $\leq 60 \%$ pengeluaran total, sedangkan proporsi pengeluaran pangan dikatakan tinggi jika bernilai sebesar $>60 \%$ pengeluaran total.

\section{Konsumsi Pangan Rumah Tangga}

Konsumsi pangan rumah tangga didapatkan melalui wawancara menggunakan metode Food Frequency Questionaire (FFQ) yang memfokuskan pada kekerapan konsumsi makanan pada subjek ditambah dengan informasi kuantitatif jumlah makanan yang dikonsumsi setiap porsi makan (Sirajuddin et al. 2018). Data konsumsi pangan yang diperoleh dari metode tersebut dikonversikan ke dalam satuan energi (kkal) dan protein (gram) dengan menggunakan Daftar Komposisi Bahan Makanan (Kementerian Kesehatan 2018). Konversi dihitung menggunakan rumus sebagai berikut ini:

$$
G(e / p)=\frac{B P}{100} \times \frac{B D D}{100} \times K G(e / p)
$$

Keterangan:

$$
\mathrm{G}(\mathrm{e} / \mathrm{p}) \quad \text { : Energi atau protein yang dikonsumsi dari bahan pangan }
$$

BP : Berat bahan pangan yang dikonsumsi (gram)

BDD : Bahan pangan yang dapat dimakan (\%)

$\mathrm{KG}(\mathrm{e} / \mathrm{p}) \quad$ : Kandungan gizi energi atau protein dalam 100 gram

(Sumber: Perdana dan Hardinsyah, 2013)

Data TKE dan TKP merupakan data konsumsi energi dan protein yang digunakan individu ataupun keluarga dengan membandingkan konsumsi energi dan protein aktual (nyata) dengan angka kecukupan energi yang dinyatakan dalam persen. Untuk menilai TKE rerata suatu rumah tangga diperlukan angka kecukupan energi rerata rumah tangga (AKERT) dan untuk menilai TKP rerata suatu rumah tangga diperlukan angka kecukupan protein rerata rumah tangga (AKPRT). Angka tersebut merupakan hasil penjumlahan angka kecukupan energi dan protein setiap anggota rumah tangga yang mengonsumsi makanan dibagi dengan jumlah anggota rumah tangga itu sendiri (Hardinsyah dan Martianto, 1992 dalam Ashari, 2017). AKERT dapat dihitung dengan rumus sebagai berikut:

Keterangan:

$$
\mathrm{AKErt}=\frac{\sum \mathrm{AKEi}}{\mathrm{n}}
$$

AKErt : Angka Kecukupan Energi Rerata Rumah Tangga (kkal/kap/hari)

AKEi : Angka Kecukupan Energi Individu (kkal/kap/hari)

$\mathrm{n} \quad$ : Jumlah anggota rumah tangga 
Prinsip yang digunakan untuk menaksir kecukupan protein keluarga sama dengan menaksir kecukupan energi keluarga. Perhitungannya adalah sebagai berikut:

$$
\mathrm{AKPrt}=\frac{\sum \mathrm{AKPi}}{\mathrm{n}}
$$

Keterangan:

AKPrt : Angka Kecukupan Protein Rerata Rumah Tangga

AKPi : Angka Kecukupan Protein Individu (gr/kap/hari)

$\mathrm{n} \quad$ : Jumlah anggota rumah tangga

Angka kecukupan energi dan protein individu pada setiap anggota keluarga dibedakan menurut usia dan jenis kelamin. Ketentuan Angka Kecukupan Energi (AKE) dan Angka Kecukupan Protein (AKP) yang digunakan berdasarkan Peraturan Menteri Kesehatan Republik Indonesia No. 75 Tahun 2013 tentang Angka Kecukupan Gizi yang dianjurkan bagi masyarakat Negara Republik Indonesia berdasarkan usia dan jenis kelamin. Untuk mengetahui TKE dan TKP maka dilakukan pembandingan antara angka konsumsi energi dan protein aktual dengan angka kecukupan energi dan protein yang dianjurkan yang dinyatakan dalam persen. Penilaian tersebut dapat digunakan untuk individu maupun keluarga. TKE dihitung dari data konsumsi pangan dihitung dengan menggunakan rumus:

$$
\mathrm{TKE}=\frac{\text { Rata-rata konsumsi energi aktual rumah tangga }}{\text { Rata-rata Angka Kecukupan Energi (AKE) rumah tangga }} \times 100 \%
$$

Prinsip yang digunakan untuk menaksir kecukupan protein keluarga sama dengan menaksir kecukupan energi keluarga. Perhitungannya adalah sebagai berikut:

$$
\mathrm{TKP}=\frac{\text { Rata-rata konsumsi protein aktual rumah tangga }}{\text { Rata-rata Angka Kecukupan protein (AKP) rumah tangga }} \times 100 \%
$$

TKE sebagai indikator kecukupan energi dibagi menjadi dua kategori yaitu cukup $(\geq 70 \%)$ dan kurang $(<70 \%)$. TKP sebagai indikator kecukupan energi protein dibagi menjadi dua kategori yaitu cukup ( $\geq 80 \%)$ dan kurang ( $<80 \%$ ) (Riskesdas, 2010 dalam Ashari, 2016).

\section{HASIL DAN PEMBAHASAN}

\section{Pengeluaran Rumah Tangga}

Pengeluaran keluarga dikelompokan menjadi pengeluaran pangan dan non pangan. Pengeluaran rumah tangga per kapita per bulan dihitung berdasarkan jumlah uang yang dibelanjakan untuk kebutuhan seluruh anggota keluarga yakni kebutuhan pangan maupun non pangan dalam sebulan. Pengeluaran pangan dikelompokan menjadi pengeluaran padi-padian (seperti beras, jagung, tepung terigu), umbi-umbian (seperti ubi jalar, singkong, kentang), ikan, daging, telur dan susu, sayur, kacang-kacangan (tempe, tahu, dan kacang tanah), buah, minyak dan lemak (minyak kelapa, minyak goreng, dan mentega), bahan minuman (gula pasir, gula merah, teh, kopi), bumbu-bumbuan (garam, kecap, saos, bumbu) dan lainnya (kerupuk, mie). Pengeluaran non pangan mencakup pengeluaran perumahan dan fasilitas keluarga (sewa/merawat rumah, PAM, listrik), barang dan jasa (alas kaki, bahan bakar, kebersihan dan kecantikan, rokok, transport selain anak, pendidikan, kesehatan), pakaian, barang tahan lama (sikat cuci, sapu), pajak dan asuransi (sumbangan, pajak, arisan, tabungan), serta keperluan 
pesta dan upacara atau hiburan (Badan Pusat Statistik, 2007 dalam Hildawati, 2008). Pengeluaran per kapita per bulan didapatkan dengan mengakumulasikan pengeluaran pangan dan nonpangan keluarga dengan pendekatan pengeluaran tahunan kemudian dikonversikan dalam bulan. Setelah dikonversikan dalam bulan kemudian dibagi dengan banyaknya anggota keluarga.

Berdasarkan data SUSENAS (2019), Kabupaten Aceh Besar memiliki 3 kluster pengkategorian kelompok pengeluaran. Pertama, 40 persen terendah dengan rata-rata pengeluaran total sebesar Rp 564.615, 40 yang terdiri atas pengeluaran pangan $\mathrm{Rp} 369.424$ dan pengeluaran non pangan $\mathrm{Rp} 195.191$. Kedua, 40 persen menengah dengan rata-rata pengeluaran total sebesar $\mathrm{Rp} 1.079 .691$ yang terdiri atas pengeluaran pangan $\mathrm{Rp} 654.530$ dan pengeluaran non pangan $\mathrm{Rp}$ 425.160. Ketiga, 20 persen kelompok pengeluaran teratas dengan rata-rata pengeluaran sebesar $\mathrm{Rp} 2.107 .919$ yang terdiri atas pengeluaran pangan $\mathrm{Rp} 915.033$ dan pengeluaran non pangan $\mathrm{Rp}$ 1.192.286.

Tabel 1. Minimal, maksimal dan rata-rata pengeluaran rumah tangga (Rp/kapita/bulan)

\begin{tabular}{lcccc}
\hline \multicolumn{1}{c}{ Pengeluaran Rumah Tangga } & Minimal & Maksimal & Rata-rata & Standar Deviasi \\
\hline Pengeluaran Pangan & & & & \\
RT Program & 398.703 & 760.177 & 568.170 & 83.479 \\
RT Non-program & 381.590 & 764.631 & 539.431 & 94.461 \\
$\quad$ Total & 381.590 & 764.631 & 553.800 & 89.561 \\
\hline Pengeluaran Non Pangan & & & & \\
RT Program & 300.000 & 989.400 & 518.360 & 154.089 \\
RT Non-program & 203.360 & 541.700 & 375.606 & 93.265 \\
Total & 203.360 & 989.400 & 446.983 & 145.351 \\
\hline Pengeluaran Total & & & & \\
RT Program & 728.578 & 1.749 .577 & 1.086 .530 & 213.823 \\
RT Non-program & 627.453 & 1.306 .331 & 915.036 & 172.396 \\
Total & 627.453 & 1.749 .577 & 1.000 .783 & 211.088 \\
\hline
\end{tabular}

Data primer diolah (2019)

Berdasarkan Tabel 1, kelompok penerima program dan bukan penerima program memiliki rata-rata pengeluaran total di antara kelompok pengeluaran 40 persen terendah dan 40 persen menengah. Rata-rata pengeluaran total masing-masing kedua kelompok tersebut adalah sebesar Rp 1.086.530 untuk kelompok penerima program dan Rp 915.036 untuk kelompok bukan penerima program. Perbedaan rata-rata pendapatan yang diukur melalui pengeluaran antara kelompok penerima dan kelompok bukan penerima program mengindikasikan adannya dampak program Kawasan Mandiri Pangan. Hal tersebut sesuai dengan kajian Suryahadi (2007) dalam Agustiani (2012) yang menjelaskan bahwa dampak suatu program dapat diketahui dengan melihat selisih suatu indikator antara rumah tangga program dan nonprogram. Perbedaan rata-rata pengeluaran total sebesar Rp 171.494 per kapita per bulan antara kedua kelompok mengindikasikan kelompok penerima program memiliki kemampuan lebih besar secara ekonomi dibandingkan dengan kelompok bukan penerima program.

Pada Tabel 1 dapat dilihat bahwa rata-rata pengeluaran pangan non pangan maupun secara pengeluaran total per kapita per bulan, kelompok penerima lebih tinggi dibandingkan dengan kelompok bukan penerima. Rata-rata pengeluaran pangan untuk kelompok penerima maupun bukan penerima lebih besar daripada pengeluaran pangan 40 persen kelompok pengeluaran terendah dengan jumlah masing-masing sebesar Rp 568.170 dan Rp 539.431 namun lebih rendah dari pada rata-rata pengeluaran pangan pada 2 kluster lainnya. Rata-rata pengeluaran non pangan untuk kelompok penerima maupun bukan penerima lebih besar daripada pengeluaran non pangan 40 persen kelompok terendah dengan jumlah masing-masing $\mathrm{Rp} 518.360$ dan $\mathrm{Rp}$ 375.606. Berbeda dengan rata-rata pengeluaran pangan, untuk pengeluaran 
non pangan, kelompok penerima program memiliki rata-rata pengeluaran non pangan yang juga lebih besar daripada 40 persen kelompok pengeluaran menengah yang sebesar Rp 515.566. Hasil tersebut menunjukkan bahwa dari sisi pengeluaran non pangan, kelompok penerima berada pada kluster 40 persen kelompok menengah di Kabupaten Aceh Besar. Hasil yang sama juga ditunjukkan dari sisi pengeluaran total di mana pengeluaran total kelompok penerima dan bukan penerima lebih besar daripada 40 persen kelompok terendah namun tidak lebih besar daripada 40 persen kelompok menengah.

\section{Persentase Pengeluaran berdasarkan Jenis Pengeluaran}

Adapun besaran persentase pengeluaran rumah tangga pada kedua kelompok rumah tangga dapat dilihat pada Tabel 2 berikut.

Tabel 2. Persentase pengeluaran rumah tangga per kapita per bulan berdasarkan jenis pengeluaran

\begin{tabular}{|c|c|c|c|c|c|c|}
\hline \multirow[b]{2}{*}{ Jenis Pengeluaran } & \multicolumn{2}{|c|}{ RT Program } & \multicolumn{2}{|c|}{ RT Non-program } & \multicolumn{2}{|c|}{ Total } \\
\hline & $\begin{array}{l}\text { Sub } \\
\text { total }\end{array}$ & Total & $\begin{array}{c}\text { Sub } \\
\text { total }\end{array}$ & Total & $\begin{array}{l}\text { Sub } \\
\text { total }\end{array}$ & Total \\
\hline Pangan & & & & & & \\
\hline Padi-padian & 18,1 & 9,5 & 19 & 11,9 & 18,5 & 10,5 \\
\hline Umbi-umbian & 0,9 & 0,4 & 0,5 & 0,3 & 0,7 & 0,4 \\
\hline Ikan & 10,7 & 5,6 & 8,7 & 5,5 & 9,7 & 5,5 \\
\hline Daging & 1 & 0,5 & 0,7 & 0,5 & 0,9 & 0,5 \\
\hline Telur dan susu & 5,2 & 2,7 & 5,3 & 3,3 & 5,3 & 3 \\
\hline Sayur-sayuran & 13,9 & 7,2 & 14,3 & 8,9 & 14 & 8 \\
\hline Kacang-kacangan & 2,8 & 1,5 & 2,8 & 1,7 & 2,8 & 1,6 \\
\hline Buah-buahan & 6,4 & 3,2 & 6,9 & 4,3 & 6,7 & 3,8 \\
\hline Minyak dan lemak & 3,1 & 1,6 & 3,3 & 2,1 & 3,2 & 1,8 \\
\hline Bahan minuman & 3,2 & 1,7 & 3,4 & 2,1 & 3,3 & 1,9 \\
\hline Bumbu-bumbuan & 1,4 & 0,7 & 1,5 & 0,9 & 1,4 & 0,8 \\
\hline Makanan dan minuman jadi & 19,3 & 10,1 & 19,9 & 12,5 & 19,6 & 11,1 \\
\hline Tembakau & 14 & 7,3 & 13,7 & 8,6 & 13,9 & 7,9 \\
\hline Sub Total & 100 & 52 & 100 & 62,6 & 100 & 56,8 \\
\hline Non-pangan & & & & & & \\
\hline Perumahan dan fasilitas RT & 54,7 & 26,2 & 61,8 & 22,9 & 57,4 & 24,8 \\
\hline Aneka barang dan Jasa & 30,5 & 14,7 & 19,9 & 7,4 & 26,5 & 11,4 \\
\hline Pakaian, alas kaki dan penutup kepala & 10,4 & 5 & 12,2 & 4,5 & 11,1 & 4,8 \\
\hline Barang tahan lama & 0,8 & 0,4 & 1,6 & 0,6 & 1,1 & 0,5 \\
\hline Pajak, pungutan dan asuransi & 3,6 & 1,7 & 4,5 & 1,7 & 3,9 & 1,7 \\
\hline Keperluan pesta dan upacara & 0 & 0 & 0 & 0 & 0 & 0 \\
\hline Sub Total & 100 & 48 & 100 & 37,1 & 100 & 43,2 \\
\hline Total & & 100 & & 100 & & 100 \\
\hline
\end{tabular}

Berdasarkan Tabel 2, pengeluaran per kapita per bulan pada kelompok penerima program dan bukan penerima program didominasi oleh pengeluaran pangan dengan persentase masing-masing $52 \%$ dan $62,8 \%$ yang dihitung berdasarkan rata-rata pengeluaran pangan rumah tangga. Hasil tersebut diperkuat dengan persentase rata-rata pengeluaran pangan Kabupaten Aceh Besar memiliki proporsi sebesar 53\% terhadap pengeluaran keseluruhan (Statistik Kesejahteraan Kabupaten Aceh Besar 2019). Menurut Purwaningsih (2010) proporsi pengeluaran pangan yang lebih besar terhadap pengeluaran total suatu masyarakat ataupun rumah tangga mengindikasikan bahwa masyarakat atau rumah tangga tersebut masih belum dapat dikatakan sejahtera. 


\section{Klasifikasi Pengeluaran Berdasarkan Garis Kemiskinan dalam Rupiah}

Menurut data Badan Pusat Statistik Aceh Besar (2019), garis kemiskinan Kabupaten Aceh Besar dalam rupiah pada tahun 2019 adalah sebesar Rp 447.563 per kapita per bulan, yang berarti seseorang atau rumah tangga dikategorikan tidak miskin jika rata-rata pengeluaran selama satu bulan berada di atas jumlah tersebut. Dengan mengacu kepada jumlah garis kemiskinan tersebut dan juga dengan menggunakan rumus interval Slamet (1993) dalam Rochaeni (2013), klasifikasi pengeluaran total di kedua kelompok dibagi menjadi tiga. Menurut (Badan Pusat Statistik, 2007 dalam Hildawati, 2008), pengeluaran rumah tangga tergolong tinggi apabila pengeluaran total rumah tangga per kapita per bulan diatas 1,5 garis kemiskinan (Rp 671.345), pengeluaran rumah tangga tergolong sedang apabila pengeluaran total rumah tangga per kapita per bulan diatas garis kemiskinan dan dibawah 1,5 garis kemiskinan (Rp 671.345) dan pengeluaran rumah tangga tergolong rendah apabila pengeluaran total rumah tangga per kapita per bulan dibawah garis kemiskinan.

Tabel 3. Klasifikasi pengeluaran total rumah tangga berdasarkan garis kemiskinan

\begin{tabular}{lcccccc}
\multicolumn{1}{c}{ Klasifikasi Pengeluaran Total } & \multicolumn{2}{c}{ RT Program } & RT Non-program & \multicolumn{2}{c}{ Total } \\
\cline { 2 - 7 } & $\mathrm{n}$ & $\%$ & $\mathrm{n}$ & $\%$ & $\mathrm{n}$ & $\%$ \\
\hline Rendah $(<\mathrm{GK})$ & 0 & 0,0 & 0 & 0,0 & 0 & 0,0 \\
Sedang $(1.0-1.5 \mathrm{GK})$ & 0 & 0,0 & 1 & 3,3 & 1 & 1,7 \\
Tinggi $(>1.5 \mathrm{GK})$ & 30 & 100,0 & 29 & 96,7 & 59 & 98,3 \\
\hline Rata-rata \pm & $1.086 .530 \pm$ & \multicolumn{2}{c}{$915.036 \pm$} & \multicolumn{2}{c}{$1.000 .783 \pm$} \\
Standar Deviasi & \multicolumn{2}{c}{213.823} & \multicolumn{2}{c}{172.396} & 211.088 \\
\hline
\end{tabular}

Data primer diolah (2019)

Berdasarkan Tabel 3, dapat diketahui bahwa secara keseluruhan klasifikasi pengeluaran rumah tangga tergolong tinggi. Hasil tersebut ditunjukkan dari besaran persentase pengeluaran dengan klasifikasi tinggi yaitu sebesar 98,3\%, dan hanya terdapat satu rumah tangga dari kelompok bukan penerima program dengan klasifikasi pengeluaran sedang dengan $(1,7 \%)$. Berdasarkan hasil tersebut dapat disimpulkan bahwa sebagian besar rumah tangga pada kedua kelompok responden mampu memenuhi kebutuhan pokok rumah tangganya baik kebutuhan akan pangan maupun non-pangan. Tingkat pengeluaran pangan rumah tangga atau proporsi pengeluaran pangan merupakan biaya yang dikeluarkan untuk pangan oleh suatu rumah tangga dalam waktu setiap bulannya dan membandingkannya dengan pengeluaran total per bulan.

\section{Klasifikasi Proporsi Pengeluaran Pangan}

Berdasarkan analisis terhadap salah satu karakteristik rumah tangga berdasarkan pengukuran ketahanan pangan rumah tangga yaitu variabel pengeluaran rumah tangga, didapat hasil untuk proporsi pengeluaran pangan pada Tabel 4 berikut.

Tabel 4. Tingkat proporsi pengeluaran pangan

\begin{tabular}{lcccccc}
\hline \multirow{2}{*}{ Kriteria } & \multicolumn{2}{c}{ RT Program } & \multicolumn{2}{c}{ RT Non-program } & \multicolumn{2}{c}{ Total } \\
\cline { 2 - 8 } & $\mathrm{n}$ & $\%$ & $\mathrm{n}$ & $\%$ & $\mathrm{n}$ & $\%$ \\
\hline Rendah ( $\leq 60 \%$ pengeluaran total) & 26 & 86,7 & 22 & 73,3 & 48 & 80,0 \\
Tinggi (>60\% pengeluaran total) & 4 & 13,3 & 8 & 26,7 & 12 & 20,0 \\
\hline Rata-rata \pm Standar Deviasi & \multicolumn{2}{c}{$53 \pm 5,7$} & \multicolumn{2}{c}{$59 \pm 4,8$} & & $56 \pm 6,1$ \\
\hline
\end{tabular}

Data primer diolah (2019)

Tingkat pengeluaran pangan merupakan bagian dari pengukuran ketahanan pangan dengan metode Maxwell. Tingkat pengeluaran pangan dan tingkat ketahanan pangan berhubungan terbalik, yang berarti semakin besar tingkat pengeluaran pangan suatu rumah tangga, maka semakin rendah tingkat ketahanan pangan rumah tangga tersebut, begitu juga sebaliknya. Tingkat pengeluaran pangan rumah tangga pada penelitian ini dikategorikan 
menurut metode pengukuran ketahanan pangan rumah tangga Maxwell et al. (1992). Tabel 4 menunjukkan bahwa sebagian besar tingkat pengeluaran rumah tangga pada kelompok penerima $(86,7 \%)$ dan kelompok bukan penerima $(73,3 \%)$ termasuk dalam kategori tingkat proporsi pengeluaran pangan rendah, yang berarti kedua kelompok responden dari dimensi pengeluaran pangan sebagian besar tergolong baik. Tingkat pengeluaran tergolong rendah berarti bahwa kurang dari $60 \%$ bagian dari pendapatan rumah tangga dibelanjakan untuk pangan dan berpeluang lebih untuk mengalokasikan pendapatan rumah tangga untuk kebutuhan non-pangan lainnya maupun sebagai tabungan (Arida et al. 2015 dan Purwaningsih et al. 2010). Hasil uji Mann-Whitney menunjukkan bahwa terdapat perbedaan yang signifikan antara persentase pengeluaran pangan pada kedua kelompok (nilai $\mathrm{P}=0,000$ ).

\section{Konsumsi Pangan Rumah Tangga}

Komponen nutrisi atau zat gizi sebagai sub bab konsumsi pangan rumah tangga yang dihitung pada penelitian ini adalah asupan energi dalam satuan kkal dan protein dalam satuan gr. Penentuan Angka Kecukupan Energi (AKE) dan Angka Kecukupan Protein (AKP) mengacu pada angka kecukupan gizi (AKG 2013) yang disepakati pada Widyakarya Nasional Pangan dan Gizi (WNPG) tahun 2012 di Jakarta. AKG 2013 ini juga telah ditetapkan pada Peraturan Menteri Kesehatan (Permenkes) Republik Indonesia Nomor 75 Tahun 2013 tentang Angka Kecukupan Gizi Yang Dianjurkan Bagi Bangsa Indonesia. Berdasarkan analisis konsumsi zat gizi energi dan protein rumah tangga yang kemudian dikonversikan ke dalam satuan kapita per hari maka didapat hasil pada Tabel 5 berikut.

Tabel 5. Rata-rata tingkat konsumsi energi dan protein rumah tangga per kapita per hari

\begin{tabular}{lccc}
\hline \multirow{2}{*}{ Variabel } & RT Program & RT Non-program & Total \\
\cline { 2 - 4 } & Rata-rata \pm SD & Rata-rata \pm SD & Rata-rata \pm SD \\
\hline Energi & & & \\
Konsumsi Aktual (kkal/kap/hari) & $1579,8 \pm 145,5$ & $1547,2 \pm 122,3$ & $1563,5 \pm 134,3$ \\
Angka Kecukupan (kkal/kap/hari) & $2291,9 \pm 109,5$ & $2328,6 \pm 130,7$ & $2310,2 \pm 121,0$ \\
Tingkat Kecukupan (\%) & $69,0 \pm 6,7$ & $66,6 \pm 6,1$ & $67,8 \pm 6,5$ \\
\hline Protein & & & \\
Konsumsi Aktual (gr/kap/hari) & $44,5 \pm 5,0$ & $41,9 \pm 6,9$ & $43,2 \pm 6,1$ \\
Angka Kecukupan (gr/kap/hari) & $60,1 \pm 4,0$ & $60,0 \pm 3,7$ & $60,1 \pm 3,8$ \\
Tingkat Kecukupan (\%) & $74,4 \pm 10,2$ & $69,9 \pm 11,5$ & $72,2 \pm 11,0$ \\
\hline
\end{tabular}

Data primer diolah (2019)

Pada Tabel 5, menunjukkan bahwa rerata konsumsi energi rumah tangga pada kelompok penerima yaitu $1579,8 \mathrm{kkal} / \mathrm{kap} /$ hari sedangkan pada kelompok bukan penerima yaitu 1547,2 kkal/kap/hari. Hasil uji Mann-Whitney menunjukkan bahwa tidak terdapat perbedaan yang signifikan antara konsumsi energi aktual pada kelompok penerima dan kelompok bukan penerima ( $>00,05$ ). Rerata Angka Kecukupan Energi (AKE) pada kelompok penerima yaitu 2291,9 kkal/kap/hari, sedangkan pada kelompok bukan penerima yaitu 2328,6 kkal/kap/hari. Hasil uji Mann-Whitney menunjukkan bahwa tidak terdapat perbedaan yang signifikan antara angka kecukupan energi pada kelompok penerima dan kelompok bukan penerima program ( $\mathrm{p}>0,05)$.

Rerata Tingkat Kecukupan Energi (TKE) rumah tangga kelompok penerima lebih besar dibandingkan dengan kelompok bukan penerima namun nilai rerata dari kedua kelompok tersebut masih berada di bawah kriteria kecukupan energi oleh Riskesdas (2010) dalam Ashari (2016). Hasil ini juga sejalan dengan hasil Studi Diet Total (2014) bahwa secara nasional rerata asupan energi penduduk Indonesia per kapita per hari lebih rendah dari rerata AKEnya. Hasil uji Mann-Whitney menunjukkan bahwa tidak terdapat perbedaan yang signifikan antara tingkat kecukupan energi pada kelompok penerima dan kelompok bukan penerima program ( $p>0,05)$. 
Pada Tabel 5, menunjukkan bahwa rerata konsumsi protein pada kelompok penerima yaitu 44,5 g/kap/hari sedangkan pada kelompok bukan penerima yaitu 41,9 g/kap/hari. Hasil uji Mann-Whitney menunjukkan bahwa tidak terdapat perbedaan yang signifikan antara konsumsi protein aktual pada kelompok penerima dan kelompok bukan penerima ( $>>0,05)$. Rerata Angka Kecukupan Protein (AKP) pada kelompok penerima dan kelompok bukan penerima yaitu 60,0 g/kap/hari. Hasil uji Mann-Whitney menunjukkan bahwa tidak terdapat perbedaan yang signifikan antara angka kecukupan protein pada kelompok penerima dan kelompok bukan penerima program $(\mathrm{p}>0,05)$.

Rerata Tingkat Kecukupan Protein (TKP) pada kelompok penerima yaitu 74,4\%, sedangkan pada kelompok bukan penerima yaitu $69,9 \%$. Hasil ini tidak sejalan dengan hasil Studi Diet Total (2014) yang mengatakan bahwa secara nasional rerata asupan protein penduduk Indonesia per orang per hari lebih tinggi dari AKP. Hasil uji Mann-Whitney menunjukkan bahwa tidak terdapat perbedaan yang signifikan antara tingkat kecukupan protein pada kelompok penerima dan kelompok bukan penerima program $(p>0,05)$.

\section{Klasifikasi Tingkat Kecukupan Energi dan Tingkat Kecukupan Protein}

Pengkategorian TKE dan TKP pada penelitian ini didasarkan pada Riskesdas (2010) dalam Ashari (2016) yang dapat dilihat pada Tabel 6 berikut.

Tabel 6. Tingkat kecukupan energi dan protein (TKE dan TKP)

\begin{tabular}{|c|c|c|c|c|c|c|}
\hline \multirow{2}{*}{ Kriteria } & \multicolumn{2}{|c|}{ RT Program } & \multicolumn{2}{|c|}{ RT Non-program } & \multicolumn{2}{|c|}{ Total } \\
\hline & $\mathrm{n}$ & $\%$ & $\mathrm{n}$ & $\%$ & $\mathrm{n}$ & $\%$ \\
\hline \multicolumn{7}{|l|}{ Klasifikasi TKE } \\
\hline Cukup ( $\geq 70 \%)$ & 17 & 56,7 & 12 & 40,0 & 29 & 48,3 \\
\hline Kurang $(<70 \%)$ & 13 & 43,3 & 18 & 60,0 & 31 & 51,7 \\
\hline Rata-rata \pm Standar Deviasi & \multicolumn{2}{|c|}{$69,0 \pm 6,7$} & \multicolumn{2}{|c|}{$66,6 \pm 6,1$} & \multicolumn{2}{|c|}{$67,8 \pm 6,5$} \\
\hline \multicolumn{7}{|l|}{ Klasifikasi TKP } \\
\hline Cukup ( $\geq 80 \%)$ & 11 & 36,7 & 7 & 23,3 & 18 & 30,0 \\
\hline Kurang $(<80 \%)$ & 19 & 63,3 & 23 & 76,7 & 42 & 70,0 \\
\hline Rata-rata \pm Standar Deviasi & \multicolumn{2}{|c|}{$74,4 \pm 10,2$} & \multicolumn{2}{|c|}{$69,9 \pm 11,5$} & \multicolumn{2}{|c|}{$72,2 \pm 11,0$} \\
\hline
\end{tabular}

Data primer diolah (2019)

Pada Tabel 6 di atas diketahui bahwa sebagian besar TKE rumah tangga pada kelompok penerima termasuk dalam kategori cukup $(56,7 \%)$, sedangkan rumah tangga bukan penerima sebagian besar temasuk dalam kategori kurang (60,0\%). Sedangkan untuk TKP, kedua kedua kelompok rumah tangga penerima dan bukan penerima sebagian besar termasuk dalam kategori kurang dengan nilai masing-masingnya $63,3 \%$ dan 76,7\%. Secara keseluruhan dapat diketahui bahwa tingkat kecukupan energi dan protein pada kedua kelompok responden sebagian besar masih termasuk kurang dengan nilai TKE sebesar 51,7\% dan nilai TKP sebesar 70\%. Hasil uji Mann-Whitney menunjukkan bahwa variabel tingkat konsumsi energi dan protein tidak terdapat perbedaan yang signifikan pada kedua kelompok dengan nilai signifikansi masing-masing nilai $\mathrm{P}=0,074$ dan $\mathrm{P}=0,115$.

\section{KESIMPULAN DAN SARAN}

Hasil analisis tingkat proporsi pengeluaran pangan menunjukkan bahwa sebagian besar tingkat pengeluaran rumah tangga pada kelompok penerima $(86,7 \%)$ dan kelompok bukan penerima $(73,3 \%)$ termasuk dalam kategori rendah, yang berarti kedua kelompok responden dari dimensi pengeluaran pangan sebagian besar tergolong baik. Hasil uji Mann-Whitney menunjukkan bahwa terdapat perbedaan yang signifikan antara persentase pengeluaran pangan 
pada kedua kelompok (nilai $\mathrm{P}=0,000$ ). Hasil TKE dan TKP menunjukkan bahwa TKE kelompok penerima termasuk dalam kategori cukup (56,7\%), sedangkan rumah tangga bukan penerima sebagian besar temasuk dalam kategori kurang $(60,0 \%)$. TKP pada kedua kedua kelompok rumah tangga penerima dan bukan penerima sebagian besar termasuk dalam kategori kurang dengan nilai masing-masingnya $63,3 \%$ dan $76,7 \%$. Secara keseluruhan dapat diketahui bahwa tingkat kecukupan energi dan protein pada kedua kelompok responden sebagian besar masih termasuk kurang dengan nilai TKE sebesar 51,7\% dan nilai TKP sebesar 70\%. Hasil uji Mann-Whitney menunjukkan bahwa variabel tingkat konsumsi energi dan protein tidak terdapat perbedaan yang signifikan pada kedua kelompok dengan nilai signifikansi masing-masing nilai $\mathrm{P}=0,074$ dan $\mathrm{P}=0,115$. Berdasarkan hasil tersebut dapat disimpulkan bahwa sebagian besar rumah tangga perlu memenui kecukupan energi dan protein dengan mengkonsumsi bahan makanan yang sehat, bergizi dan beragam sesuai dengan konsep Pola Pangan Harapan (PPH) yang dirumuskan Badan Ketahanan Pangan Negara-Kementerian Pertanian Republik Indonesia.

\section{DAFTAR PUSTAKA}

Arikunto, S. 2013. Prosedur Penelitian: Suatu Pendekatan Praktik. Rineka Cipta. Jakarta.

Arida, A., Sofyan dan K. Fadhiela. 2015. Analisis Ketahanan Pangan Rumah Tangga Berdasarkan Proporsi Pengeluaran Pangan dan Konsumsi Energi (Studi Kasus pada Rumah Tangga Petani Peserta Program Desa Mandiri Pangan di Kecamatan Indrapuri Kabupaten Aceh Besar). Jurnal Agrisep. 16(1): 20-34.

Ashari, C.R. 2017. Studi Analisis Ketahanan Pangan pada Rumah Tangga Miskin Perkotaan dan Pedesaan di Sulawesi Selatan. Thesis. Institut Pertanian Bogor. Bogor.

Badan Ketahanan Pangan. 2015. Panduan Penghitungan Pola Pangan Harapan (PPH). Badan Ketahanan Pangan Kementerian Pertanian Republik Indonesia. Jakarta.

Badan Pusat Statistik. 2019. Aceh Besar dalam Angka 2019. Banda Aceh.

Badan Pusat Statistik. 2019. Statistik Kesejahteraan Rakyat Kabupaten Aceh Besar 2019. Banda Aceh.

Hildawati, I. 2008. Analisis Akses Pangan Serta Pengaruhnya terhadap Tingkat Konsumsi Energi dan Protein pada Keluarga Nelayan. Skripsi. Institut Pertanian Bogor. Bogor.

Maxwell, S., T.R. Frankerberger. 1992. Household Food Security: Concepts, Indicators, Measurement: A technical Review. International Fund for Agriculture Development/United Nations Children's Fund. Rome.

Perdana, F. dan Hardinsyah. 2013. Analisis Jenis, Jumlah dan Mutu Gizi Konsumsi Sarapan Anak Indonesia. Jurnal Gizi dan Pangan. 8(2): 39-46.

Purwaningsih, Y., S. Hartono, Masyhuri dan J.H. Mulyo. 2010. Pola Pengeluaran Pangan Rumah Tangga Menurut Tingkat Ketahanan Pangan di Provinsi Jawa Tengah. Jurnal Ekonomi Pembangunan. 11(2): 236-253.

Rochaeni, S. 2013. Analisis Persepsi, Kesadaran dan Preferensi Konsumen terhadap Buah Lokal. Jurnal Agribisnis. 7(1): 91-104.

Sirajuddin, Surmita, T. Astuti. 2018. Survey Konsumsi Pangan. Pusat Pendidikan Sumber Daya Manusia Kesehatan-Kementerian Kesehatan Republik Indonesia. Jakarta. 